\title{
Staff Preferences in Four SMEs Experiencing Organizational Change
}

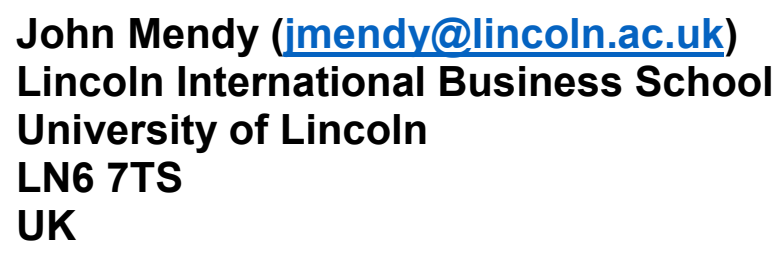

\begin{abstract}
Purpose - The purpose of this paper is to investigate the role of preferences when SMEs are confronted with the practical problems associated with implementing frequent and large scale changes to their working policies and practices. This paper aims to alleviate some of the concerns as claimed in positioning and change agency theory by introducing 'preferential role positioning' to organizational change.
\end{abstract}

Design/Methodology/approach - This study uses a qualitative case study approach and change agency and positioning theories to find out the extent to which staff and management experienced the practical difficulties and challenges and what resolution actions they took. Eighty-five semi-structured interviews were conducted in 2004/05 and 2011 with the staff and management of four SMEs in the UK. An interpretative analysis was conducted on the case data in the tradition of Husserl and Schutz. In the first set, participants were asked to elucidate the difficulties faced in their roles and how these were experienced whilst the second focused on impacts and strategies. Three independent researchers reviewed and interpreted the qualitative data and helped with the coding and thematisation.

Findings - This paper's main results are based on the data's three stages showing how SME members chose to deal with the practical difficulties namely 'new structures and procedures' (stage 1); 'new ways of communicating' (stage 2) and 'new collaborations' (stage 3). The combination of the stages' aspects led to the emergence of 'preferential role positioning' as the study's theoretical contribution to the gap on preferences in organizational change research.

Research limitations - The eighty-five interviews from UK-based SMEs constrained the sample size thereby limiting the number of questionnaire categories asked. The findings and their analysis cannot be generalised to non SMEs that seek to address similar difficulties.

Practical implications - Managers need to be aware of the adverse impacts of using draconian, top down disciplinary and punishment measures/structures as a way to implement change. 
Other practical lessons include the fact that managers should contextualise people's anxieties, dissatisfaction, resistance and disengagement as a platform from which social knowledge can be generated with all change agents in order to resolve implementation challenges in the longer term. Staff developed the ability to deal with some practical issues such as navigating through the new departmental structures, new working procedures and new ways of talking with management and with each other to implement change more successfully.

Social implications - The social value of the findings demonstrate that preferences can be imported from other social science disciplines into Organizational Studies to show the value of what people can contribute and how they choose to do so (i.e. via what discourse, using what types of interactions and capabilities to do so). In addition, the results show that management need to consider employees in their plans as they try to implement change firstly to facilitate greater interaction and success, secondly to minimise implementation difficulties and thirdly as a recognition that there are multiple change agents and multiple role-enacting positions in developing sociological knowledge that can be of value.

Originality/value - This study's three-stage approach has shown that a successful implementation and management of change in SMEs should also include a bottom-up recognition of the difficulties, adversities, conflicts and tensions and a resolution to deal with the structural and communicative constraints via dialogue and 'preferential role positioning'

Keywords: staff, management, preferences, SMEs, organizational change

\section{INTRODUCTION}

As organizations continue to face the difficulties of managing change, sometimes managers make use of traditional theories such as change agency and paradox theories to try and resolve some of the practical issues (Barratt-Pugh and Gakere, 2013; Smith and Lewis, 2011). However, the generally planned and linear approaches that they adopt appears to be at odds with the scale, complexity and non-linearity, disorderly and frequent nature of changes (Balogun and Hope Hailey, 2004; Burnes, 2004; Prigogine and Stengers, 2018). Indeed outcomes become elusive as management's strategies are scrutinised (Senior, 2002). Examples of some of the difficulties include managers and employees having to implement and adapt to the new structures, processes and capabilities so as to effectively deal with the pace and magnitude of market pressures, external agencies' regulatory frameworks and customer 
demands. There is evidence in the literature that these are becoming more dynamic as organizations and their management challenge employees to contribute differently (Kelly and Amburgey, 1991; Helfat and Peteraf, 2003). It is claimed doing so will minimise organizational inertia, rekindle capabilities, and save companies thereby adding value (Mendy, 2019).

However, the role of staff in what is proposed is largely downplayed at best or not reported at all except when intentions are included (Camaioni, 2017). An attempt is made to explore two predominant theories in organizational change research: change agency and positioning theory to see what they can contribute in alleviating some of the concerns as claimed. Organizational change is taken to signify moving from a company's current situation to a more effective state (Cummings and Worley, 2005) or in other words, a new direction (Brightman and Moran, 2001). Despite the propositions, the theories and approaches pose contradictions, empirical data are lacking and the nature of the difficulties remain confusing (Todnem By, 2005). Part of what has been proposed involves the introduction of new interaction mechanisms or structures, which might alleviate management's practical implementation concerns (Reckwitz, 2002). However, others have proposed agency and non-humans (Buchanan and Storey, 1997; Latour, 2005). This might involve learning and renewal (Pryor et al., 2007; Wischnevsky et al., 2004) although it is not guaranteed that the non-human elements can deal with contradictions and concerns whilst rekindling what might still be missing (e.g. staff preferences). Researchers have attempted to fill this gap by using paradox theory (Smith and Lewis, 2011) or analysing what people contribute to the non-human - e.g. their situation/context (Bovey and Hede, 2001) and how these are interpreted (Myers (2013). However, there is limited success registered, partly caused by the generally confusing and dichotomised nature of the debates, taking away what could have been contributed (Burnes, 2004). This has led to two competing paradigms: discourse or practice, whose thinking is explored to see how they could address the concerns as claimed.

Researchers who subscribe to the discourse thinking claim stories and mythologies can help to narrate change experiences (Bathurst and Monin, 2010; Vaara and Tienari, 2011). They claim to highlight the paradoxical nature (Rouleau and Balogun, 2011) of contributions. Conversations between the participants, when reported, are claimed to deepen our sensemaking. Yet, what lies behind these are under-represented preferences as the narratives used remain bi-polarised and the real-life aspects are not deeply analysed (Yin, 2003). They fail to address concerns regarding not only pace but also the appropriate change processes and approaches required to be successful. This begs the question 'how can the preferences of two 
distinct role groups be captured and reported in a way that might alleviate part of the concerns claimed in organizational change?'

Attempts have been made to respond to this question through practice thinking. It is claimed organizational members use cultural norms (Orlikowsky, 2007) to understand their social contexts and help in dealing with the practical difficulties. Some propose 'phronesis' as an additional way (Gunder, 2010; Jansson, 2014) but this dichotomises people's contributions and neglects the role of preferences in clarifying the concerns of pace and scale. When used in Psychology, Economics and Philosophy (Coppin et al., 2010; Golsteyn and Schildberg-Horish, 2017) preference denotes the utilitarian value of employees' contributions and highlights people's ability to identify what they could do. Whether this helps in highlighting change concerns is overlooked. The closest form of research on preferences in Organizational Studies is on attitudes or reactions (Piderit, 2000). Sadly, preferences (the ability of individuals to make a choice of how they wish to practise their role, who they choose to interact with, at what level and stage) and what it could contribute to organizational change remain neglected (Mendy, 2018).

\section{RESEARCH On ORGANIZATIONAL CHANGE}

When preference research is explored in Economics, it is taken to refer to how people increase their utilitarian value when making choices or decisions. However, this has not been linked to their role or whether stages could be used to reflect any change(s). Two theories appear to dominate the debates on organizational change: change agency and positioning theory (see next two sections). One would have expected that they would explore and attempt to fill the important void that preferences has created as argued in addition to addressing the need for empirical data and theoretical clarification (see earlier concerns). After coding the data, checking the themes, and grouping these with the assistance of two other researchers, three stages led to 'preferential role positioning' as part of the paper's contribution in alleviating some of the concerns caused in this area. The introduction of preferences to positioning theory (Kjaerbeck, 2017) shows what was contributed, how employees enacted their roles and the stages/various forms/approaches used to highlight the value of their contributions in facilitating the pace and scale of change, as contextualised. It serves as an alleviation of some of the concerns and an extension to the change agency and positioning theory framework.

\section{Change agency theory}


Change agency (Barratt-Pugh and Gakere, 2013) and paradox theories (Smith and Lewis, 2011) have partially explained people's actions (Rouleau and Balogun, 2011) when organizations deal with complex difficulties. The discourse and practice approaches have also offered limited clarification as argued. Change agency (Smith and Lewis, 2011) bi-polarises the debate between management who do the 'proper' things and employees as 'obstacles or barriers' (Ford et al., 2008, p. 362). This type of reporting misses the complexity of what might have caused the nature of the difficulties (Bovey and Hede, 2001; Buchanan and Badham, 1999) and deepens contradictions. Other researchers claim resistance theory (Bovey and Hede, ibid) and propose counter measures (Knowles and Linn, 2004b) to minimise further contradictions when

participants resort to power and politicking. However, these have not properly addressed the anxieties (Sanders et al., 2014) as the involvement of multiple change agents (Caldwell, 2003; Barratt-Pugh and Gakere, 2013) and their contributions are missed. To fill this gap positioning theory is explored next.

\section{Positioning theory}

It is claimed that positioning theory (James, 2010; 2014; Kjaerbeck, 2017) might help address some of the concerns at the practical level (i.e. implementing and managing change procedures). This theory claims that when people use their positions to communicate (Day and Kjaerbeck, 2013) they enhance their role and are involved. It is opined using narratives might help (Yin, 2003). Proponents also claim that the emerging discourse is part of a set of beliefs (Harre, 2012) although their impact on cultural norms (Orlikowsky, 2007) and whether these could be linked to staff preferences is under-reported. James (2014) attempted to plug the gap by including strategic communication whilst Camaioni (2017) looked into communicative intentions. However, the ways and stages via which employees' preferences are communicated (i.e. via what language) and who they choose to do so with within a change context remain uncaptured. Positioning theory provides a useful, recent opening and a basis to help clarify concerns regarding the nature, pace and scale of change but not its approach and overemphasis on communication. Following the literature, the aim of this paper can therefore be summarised as follows: to minimise the concerns as claimed in positioning and change agency theory by using fieldwork data to introduce 'preferential role positioning' as part of a process of reporting staff preferences and how they choose to do so during organizational change.

\section{ORGANIZATIONAL CONTEXTS}


The study was started to explore whether preferences could help address some of the concerns noted as organizations introduce change. To see what could be added, four organizations were chosen for data collection purposes and respective company data, respondent types in both 2004/05 and 2011 and managers' and employees' socio-demographics are provided in tabulated format hereunder.

\section{Insert Table 1 here...}

\section{RESEARCH METHODOLOGY}

Two semi-structured interviews were carried out between 2004/2005 and 2011 with eightyfive managers and employees from each of the represented world regions in the four SMEs (see Table 1). The choice of selecting participants was motivated by the need to solicit a range of perspectives based on how staff conducted their positions (Kjaerbeck, 2017) to see whether preferences (Goldsteyn and Schildberg-Horish, 2017) were communicated and to what effect(s). Implications for theory and HR policy and practice (re-)formulation are explored in the conclusion.

This study is based on a qualitative, case study approach which has been described in the literature as the exploration of a phenomenon within a real-life or organizational situational/contextual setting (Yin, 2003). A case study is used because it provides a useful and insightful tool to study life situations and to deepen meaning of participants' (e.g. employees and managers') experiences, stories and actions (Welch et al., 2011 - see Tables 3, 4, 5 and 6). The justification for the adequacy and appropriateness of such a choice is premised on the argument based on Darcy et al.'s (2014) notion of organizational sustainability given the challenges of change the SMEs in this study faced. Hill and Lent's (2006) meta-analytical work also highlights that small firms' investigative research is best accomplished by using case studies and interviews to properly look into adverse experiences like change (Eisenhardt, 1989). Others tend to mix these methods with participant observation although there is the attendant difficulty of researcher/observer bias. In order to avoid such bias, this study adhered to the use of interview and case study materials (see Table 3). The main difficulty experienced in this study was the limited number of firms that were experiencing the change adversities mentioned and this might have constrained the nature of the question categories posed. As a way of surmounting this difficulty and capture the varied challenges and the management and employee responses and actions, a semi-structured interview format was adopted at both 
interview rounds (see Table 2). Furthermore, this study was interested in how employees made use of their preferences as the changes were being implemented rather than an attempt to stretch resources in validating the actions of management and staff longitudinally as acknowledged by Elliot (1991) and his followers.

According to Yin (1994) the process of getting from the identification of the attendant question(s) to the attainment/achievement of the research aims and objectives entails a process of research which was duly followed here. Yin (ibid) and Miles and Huberman, (1994) noted the identification of a relevant research question as an essential protocol item which was done by undertaking a systematic analysis of the relevant theoretical frameworks of positioning and change agency. This set the foundation for the identification of appropriate interview questions and guidelines for the case study's data collection and a process of analysing these (see Table 2). Such an iterative approach (Lewis, 1998) was also chosen because it ensures adequate definition of the contextual situation and the development of conceptual contribution(s) (Eisenhardt, 1989). This has been inherently the study's purpose. Such a systematic process increases not only the study's credibility and meaning-making process (Husserl, 1965) but also heightens the surfacing of key phenomenological aspects (Schutz, 1967) in each of the stages identified from the collected data (Eisenhardt and Graebner, 2007). See Table 2 below for the main methodological aspects.

\section{Insert Table 2 here...}

The data were reviewed by three independent researchers, codes were given to emerging themes using axial coding and broadly categorised in groups. A follow-up examination with two colleagues narrowed the themes further from six to three. Their reporting also fitted into three stages in the next section primarily 1) new structures and procedures, 2) new ways of communicating and 3) new collaborations whose overall summation showed how staff made their preferences on each change occasion felt in the form of a story as evidenced in Denzin and Lincoln's (2002) and Camaioni's (2017) works. Overall, the three stages appear to follow a storyline as captured in the literature (Day and Kjaerbeck, 2013; James, 2014) but one that is presented and argued as based on communicating a variety of preferences as contributions to help alleviate theoretical and practical concerns in organizational change research and practice. 
In summary the qualitative approach identified an interpretive case study as the most suitable tool to study people's preferences in four SMEs experiencing changes to their working practices and procedures. The case study is appropriate to investigate a current and contextually/situationally specific phenomenon (i.e. organizational members experiencing changes in their working environment). The data collection involved a certain research protocol in terms of the types of questions asked and associated interview guidelines, the quality of the data sought, the iterative checks with participants and other independent researchers, the avoidance of data misrepresentation and interpretative rigor as supported by Yin (2003) and Smith, Flowers and Larkin (2009) among others. The difficulties are also noted whilst corrective protocols have been adopted. All of the combined elements increase conceptual development, research credibility and contribution.

\section{FINDINGS and ANALYSIS}

This section reports and analyses the paper's findings. The methodological foundations explained and justified in the previous section inform and help in deepening the data analysis. This involved a process of sense making of employees' and management's preferences and the organizational contextual settings of changes in working practices and procedures following Myers (2013) and Yin (2003). Three various stages are summarised to highlight the contextual situations, the nature of the changes, staff experiences, including the actions taken to surmount the difficulties practical implementation and management issues and how the different role groups responded (see Table 3 below). When the changes started, there was an intensification of monitoring, supervision, appraisals and staff development sessions by management. A coding process was used to group participants' statements and these were taken as language they chose to communicate the three themes in compliance with Camaioni's (2017) work. However, the responses suggest a more dynamic view to James's (2014), and Kjaerbeck's (2017) and Camaioni's (2017) perspectives respectively as the various elements are developed using a three-stage approach (see Tables 4, 5 and 6). The findings, including the stages and the development of 'preferential role positioning' are an extension of Camaioni's (ibid) preintentional and intentional communication dichotomous presentation and Berger and Luckmann's (1966) sociology of communication. Various aspects of staff's and management's preferences as the way they chose to construct their situational reality of change highlighted not only what they chose or intended to communicate but what they actually did communicate in each of the four SME cases, in the 2004/05 and 2011 situations. The difficulties encountered 
and various actions taken have been extrapolated in Tables 3, 4, 5 and 6 followed by analyses of each of the three stages of change after Table 3 below:

\section{Insert Table 3 here...}

\section{Stage 1: New Structures and Procedures}

The first stage of analysing participants' preferences involved the establishment of factual information (i.e. staff and management's social and material realities in 2004/05 and 2011 and how they chose to talk about it in the traditions of Husserl (1965) and Schutz (1967)). When the changes started Managers' imposition of disciplinary measures as a way which they thought will help employees expedite tasks triggered a change in working practices and procedures similar to the linearity of Camaioni (2017) whilst creating unintended communication difficulties and opportunities for staff. Managers started new networks, brought these to employees' attention and asked that they joined as their way of dealing with the paradoxical emergence of their actions (Smith and Lewis, 2011). They set up bureaucracies as staff started to complain about the additional workloads in order to demonstrate agency (Barratt-Pugh and Gakere, 2013) and be seen to add some value (Golsteyn and Schildberg-Horish, 2017). When employees under-performed they were reprimanded or threatened with further disciplinary action (see Table 4 below), as if such actions paid some collective benefits (Mendy, 2018). A summation of the activities of the first stage highlight the need from both parties to stabilise challenging situations whilst creating additional complexities, challenges and possibilities as shown in stages two and three's developments (see Tables $5 \& 6$ hereafter).

\section{Insert Table 4 here...}

\section{Stage 2: New Ways of Communicating}

The second stage witnessed managers receiving clients' complaints about service and product quality and responded by routinizing the increase in quality inspections. Such efforts showed management's determination to bolster internal as well as external communication as they set up quality and customer satisfaction teams and conducted surveys with clients. When the external outcomes fell short of their expectations, management sent out constant notifications to internal staff via notice boards and team meetings. When employees did not comply, management intensified departmental meetings to boost communication, although such a strategy encouraged employees to begin their own communication networks by talking to 
others across departments (see Table 5 below). The need to adopt new ways of communicating highlighted the implementation difficulties sensed not only by management (Reckwitz, 2002) but staff as well. It also marked a fundamental shift from a language based on structurally improving or at times eliminating the traditional barriers of change (Ford et al., 2008) to one that tries to address people's intentions (Camaioni, 2017), attitudes (Piderit, 2000) and anxieties (Sanders et al., 2014) as a new way of resolving dissatisfaction and discontent for change.

\section{Insert Table 5 here...}

\section{Stage 3: New Collaborations}

In the third stage, staff realised the clear damage caused by management's actions as they initiated new collaborations or what Berger and Luckmann (1966) referred to as the sociology of communication. They worked with individuals across their organizations and customers/patients to help revert the ravages. They went a step further by interpreting their situation (Myers, 2013) as well as the tasks they were previously allocated by management in their own way, not from higher-ups. They thought that communicating intentions alone in the tradition of Camaioni (2017) was not adequate for preferences (the ability to contribute something of change value - Mendy, 2019) to be felt and acted upon within a change setting. In this way, staff would make these tasks achievable, more manageable and meaningful. They started to redefine tasks and their positions/roles (Kjaerbeck, 2017). They stepped up their actions by encouraging their colleagues to use their positions to communicate the purpose(s) of their actions and showed creativity (see Table 6 below). By the third stage, a completely different and new type of change had emerged, one premised on a combination of preferences and actions, capable of resolving the frequency of anxieties, dissatisfaction, detached and implementation difficulties caused by the scale of SMEs' adaptations.

\section{Insert Table 6 here...}

\section{What is Extended - 'Preferential Role Positioning'}

Based on the previous three stages, it has been shown how a research process has been systematically implemented following an establishment of the factual adversities of change, the communication of participants' preferences using a stage-by-stage meaning/sense- making process and the extraction of their essential aspects following Husserl (1965) and Yin 1994). In sum, management demonstrated an inability to communicate the new organizational 
structures and thereby such incapacity to create a richer (Geertz, 1975) counter-narrative to staff's accounts (Knowles and Linn, 2004b) led to not only a physical but also a methodological, theoretical and new cultural space (Orlikowsky, 2007). A new social reality of change had emerged (Berger and Luckmann, 1966), one in which sociological knowledge i.e. people's ability to interpret and take appropriate remedial actions regarding their organizational situations and challenges of change. Management's incompetence facilitated created a space, which allowed employees to reassert their role and contribute something that was feel respected by colleagues. When combined, the stages and the methodological protocols that guided their development (Myers, 2013) appear to tell a story (Harre, 2012), one in which employees realised the advantageous use their positions could give them. They started to communicate their value to management as the latter sought to downgrade this and incompetently. Employees appeared to have gained an upper-hand as they showed they had the ability to communicate more effectively with colleagues and with their higher-ups, even when this meant applying preferences perceived as resisting the imposed structures and procedures. These characteristics demonstrated qualities that could be categorised as having achieved strategic communicative value in the tradition of James (2014) but also developing an awareness to boost one's role and to bring a form of change employees perceive as successful. Additionally, staff preferences showed how the duality of Camaioni's (2017) communicative intentions can be extended and what the benefits of their application within change-specific contexts could be. This is what has been referred to in the paper as "preferential role positioning'. It showed how employees were capable of interacting with various parties, identified a variety of preferences in the process, used their roles to help improve the practical communication, structural and processual difficulties caused by others' actions.

When employees felt adversely challenged to meet customer and legislative demands especially at Bakkavor and Lagat, they responded appropriately by reinterpreting/redefining the procedures that management put in place and choosing which role groups they wanted to interact with. When they did so, they changed the nature of the change that was intended by management and the levels of engagement or involvement with what they perceived to be bureaucratic structures and procedures. They saw these measures as counter-productive to successful change. Employees modified their and other employees' responsibilities and the tasks they were initially contracted for as well as those that management introduced during the changes. This redefinition and shifting of roles and contributions highlighted the ways employees adapted their organizations' communication practices and structures to be in line 
with their modified positions and responsibilities (Day and Kjaerbeck, 2013). What has been added to current research is employees' use of a host of preferences (resisting, cooperating, communicating, redefining, socialising) which appeared to fit within a methodical series of stages/approaches, the combination of which highlighted the practical value they can bring to their firms even as attempts were made to suppress their contributions.

The three stages also appear to tell the story of how employees showed resilience and resolve and sometimes resistance to management's actions to help achieve 'firm survival' (Wischnevsky et al., 2004). Although attempts were made by management to counteract employees' resistance through additional reporting procedures, employees proved they were more effective than their managers to deal with concerns about working arrangements. In each of the stages, employees were seen to identify spaces where they could position their preferences within discernible organizational structures having identified management's failings in these. The ability to do so is referred to as 'preferential role positioning', the practical result of which helped to save the organizations and in redefining management policies and practices. Especially by the third stage, employees are seen to respond to their organizations' practical difficulties (e.g. responding to quality and productivity issues) in the here and now by using appropriate communication tools and strategies (i.e. discourse). Employees showed they were aware of the different roles they can play and they can choose to channel their activities (including the language they prefer to use) so as to turn dysfunctional 'obstacles and barriers' (or malfunctioning employees (Ford et al., 2008) into success stories of change.

\section{DISCUSSIONS}

Research on organizational change has attempted to identify attitudes that might help deal with some of the practical concerns of introducing and managing change (Piderit, 2000). The recommendation to use agency and positioning theory (James, 2014; Jansson, 2014) or other models to deal with inappropriate attitudes (Piderit, ibid) have not addressed barriers such as staff anxieties, dissatisfaction and disengagement. Some researchers follow discourse thinking and when this has not worked, other scholars have aligned with practical or practice based thinking, which they think will to help resolve problems related to resistance, conflicts, communication blockage and so on. The use of paradox/duality-type theory (Smith and Lewis, 2011) has also failed as it has not helped to clarify concerns and address the theoretical gap that the examination of change agency and positioning theories has uncovered in terms of preferences. The predominantly dichotomised discussions and linearity reported in the theoretical framework including the works of earlier Camaioni (2017) and .Rouleau and 
Balogun (2011), among others, have not adequately shed light on the multiplicity of agents that Barratt-Pugh and Gakere (2013) noted earlier. What the three stages have shown is how multiple participants choose to report a variety of their preferences when they function not merely as 'change recipients' or 'barriers' (Ford et al., 2008) but sometimes as 'change agents' (Caldwell, 2003), as resistors, or as cooperating individuals, but importantly as social collectives. When they built a network and used their roles as a counter-balance, they are seen to make their value felt by creating a different type of social knowledge from the ineffective management structures. In doing so, they enact (practise) different roles and the statements they use in doing so (i.e. their discourse) fit a storyline that communicates 'preferential role positioning' as staff's new socio-organizational and change reality.

This perspective is derived from a recognition that organizational change is multi-faceted and that the contributions of different organizational members cannot simply be boxed into and therefore constrained by duality/paradox (Smith and Lewis, 2011) or change agency theory (Buchanan and Badham, 1999; Ford et al., 2008) or the discourse or practice thinking. Recognising the complexity of actions and what lay behind their enactment, there was need to identify the contributions as well as the inadequacies and concerns raised by the theoretical proposals explored here. The introduction of the three stages is designed to reflect the differing views that multiple change agents can bring to their positions and the ways they choose to interact, with whom and at what stage(s) of the change process. Although Kjaerbeck (2017) had earlier identified the communicative value of positioning theory and Camaioni (2017) signalled the role of communicative intentions as part of the new developments, this paper highlights the preferences of people, the ways they positioned themselves and chose to communicate their contributions in ways that are increasingly being seen as part of a process of recognising a combination of staff preferences and the variety of ways they choose to enact their roles during change. 'Preferential role positioning' is posited as a different perspective of looking at the difficulties faced by organizational members without discounting the role that people's choices and their discourse have to play when they come under their higher-ups' scrutiny. It is posited to have benefits in helping management realise what employees can do and how their contributions could be better utilised in alleviating the theoretical and practical concerns as claimed. Some theoretical and practical implications are considered.

\section{CONCLUSION}


Organizations are having to deal with an increasing number of practical difficulties caused as a consequence of implementing change. Researchers have attempted to explain some of the concerns and confusions (Todnem By, 2005) and, where possible, made propositions (BarrattPugh and Gakere, 2013; Day and Kjaerbeck, 2013). Two of such are reported and analysed namely change agency and positioning theory. Their analysis fit within discourse and practice thinking. It is argued that these have not resolved the concerns faced by SMEs as a deeper analysis of preferences was lacking. With the help of the data, this paper proposes 'preferential role positioning' as part of a process to minimise the concerns. It serves as a recognition of the benefits to include preferences in positioning theory as this has been neglected in organizational change. This paper's research aim is achieved in the following way. Both set of interview responses (2004/05 and 2011) serve as empirical evidence, whose analysis has shown that organizational change is a multi-dimensional phenomenon (Schutz, 1967), that participants' experiences are complex and cannot be adequately reported either solely via a change agency or positioning theory angle or the discourse of practice thinking. It took two interview rounds with eighty-five staff and management-participants, three stages and a combined theoretical framework to ascertain the contribution of 'positioning role positioning' in organizational change literature. The analysis has also shown the benefit of going beyond bi-polarised reporting (Vaara and Tienari, 2011) or adopting a unilateral perspective as before (James, 2014; Kjaerbeck, 2017). The range of responses from these, their coding, review and categorisation indicate that preferences have a role to play in change and these are varied and complex. This paper's aim has been achieved.

Implications on theory have been argued to highlight that preferences has a role to play and should be added in change management research. As part of this process, it was shown that preferences can be imported from Economics, Psychology and Philosophy research into Organization Studies in general to show the social value of what people can contribute and how they choose to do so (i.e. via what discourse, communication networks, sub-cultural collaborations and using what types of interactions, role positioning (Kjaerbeck, 2017)) and even language. It was observed that a number of these aspects, when combined in three stages, have led to a process which has helped to identify the paper's theoretical contribution and termed 'preferential role positioning'.

The combination of the elements from each of the three stages of change have given staff the ability to deal with some practical issues such as navigating through the new departmental 
structures, new working procedures, new ways of talking with management and with each other and across departments as well as developing new partnerships and collaborations with other colleagues and customers. All of these required staff to include preferences as part of their roles and the need for management to recognise its benefits when implementing change. Ironically, surfacing 'preferential role positioning' via the three stages provided an opportunity to management to identify internal and external factors that can derail the implementation of successful change. The practical value of the findings is to show that HR need to consider employees in overall aspects of their resource management plans as well as in the design and implementation of change policies and practices. Inasmuch as standard job descriptions and person specifications are traditionally required to identify ideal candidates to help organizations achieve sustainable competitive advantage, the findings of the study highlight that HR's continuous use of textbook disciplinary and change processes might only serve as a temporary punitive and controlling measure. What is more beneficial in the longer term is for HR policies and practices to be more dialogic and engaging in socially constructing and using collective knowledge to facilitate greater successes during change. Secondly, adopting such a recommendation has the possibility to minimise implementation difficulties and thirdly this recognises that there are multiple change agents and multiple role-enacting positions (as an employee, as a manager, as a colleague, a friend and so on) that should help in re-shaping HR policy enactment contrary to what is proposed in the literature (Ford et al., 2008; Kjaerbeck, 2017). Employees' social preferences, skills and experiences therefore need to be taken into account within organizational change theory, discourse and practice (see the three stages). Monitoring, supervising, imposing new disciplinary regimes and applying selective redundancies in a top down manner should serve as a lesson for HR professionals to consider a more democratic way of creating bottom-up knowledge that could add real value to the lives of multitudes of change agents and thereby enhance organizational survivability (Mendy, 2019).

Limitations of the paper are the relatively small research population and the fact that the findings and their analysis cannot be generalised to all organizations that implement and have to deal with the difficulties caused by management's and employees' actions during change. The paper also looked at change agency and positioning theory although linearity and other models (Kotter and Schlesinger, 1979) could have been explored to see what they might add to positioning or preference literature. However, the journal's word limit served as an 
inspiration which also signalled the need to be disciplined and concise in the author's preferences/choices.

Future research may look into research methods or whether there might be additional/different stages that similar SMEs can use to bring about practical changes even when "preferential role positioning' is challenged because of other organizational pressures. It could also be interesting to explore whether socialization activities can help resolve some of the difficulties and role enactment issues as part of the ways in which both management and employees help to deal with the change issues identified by participants.

\section{References}

Balogun, J. and Hailey, V. H. (2008), Exploring Strategic Change, Prentice Hall, London.

Barratt-Pugh, L. and Banh Elsie Gakere, S. (2013), 'Managers as change agents: Implications for Human Resource Managers engaging with culture change', Journal of Organisational Change Management, Vol. 26, No. 4, pp. 748 - 764.

Bathurst, R. and Monin, N. (2010), 'Finding myth and motive in language: a narrative of organizational change', Journal of Management Inquiry, Vol. 19, No. 3, pp. $262-272$.

Berger, P. L. and Luckmann, T. (1966), The Social Construction of Reality, Anchor Books, New York.

Bovey, W. H. and Hede, A. (2001), 'Resistance to organizational change: the role of cognitive and affective processes', Leadership and Organizational Development Journal, Vol. 22, pp. $372-381$.

Brightman, B. K. and Moran, J. W. (2001), 'Managing organizational priorities', Career Development International, Vol. 6, No. 5, pp. 244-288.

Buchanan, D. and Badham, R. (1999), 'Politics and Organizational Change: The Lived Experience', Human Relations, Vol. 52, No. 5, pp. 609 - 629.

Buchanan, D. and Storey, J. (1997), 'Role-taking and role-switching in organizational change: the four pluralities', Innovation, organizational change and technology, pp. 127-145.

Burnes, B. (2004), Managing change: A strategic approach to organisational dynamics, Pearson Education, London.

Camaioni, L. (2017), 'The development of intentional communication: A re-analysis'. In New Perspectives in Early Communicative Development, Routledge, London, pp. 82-96. 
Coppin, G., Delplanque, S., Cayeux, I., Porcherot, C. and Sander, D. (2010), 'I'm no longer torn after choice: how explicit choices implicitly shape preferences of odors', Psychological Science, Vol. 21, No. 4, pp. 489-493.

Cummings, T.G. and Worley, C.G. (2005), Organizational Development and Change, Thomson/South Western US: Thomson/South Western.

Darcy, C., Hill, J., McCabe, T. J. and McGovern, P. (2014), 'A consideration of organisational sustainability in the SME context: A resource-based view and composite model', European Journal of Training and Development, Vol. 38, No. 5, pp. 398-414.

Day, D. and Kjaerbeck, S. (2013), 'Positioning' in the conversation analytic approach', Narrative Inquiry, Vol. 23, No. 1, pp. 16 - 39.

Denzin, N. K. and Lincoln, Y. S. (2002), The Qualitative Inquiry Reader, Sage, CA.

Ford, J.D., Ford, L.W. \& D'Amelio, A. (2008), 'Resistance to change: the rest of the story', Academy of Management, Vol. 3, No. 2, pp. 362 - 377.

Eisenhardt, K. M. (1989), 'Building theories from case study research', Academy of Management Review, Vol. 14, No. 4, pp. 532-550.

Eisenhardt, K. M. and Graebner, M. E. (2007), 'Theory building from cases: Opportunities and challenges', Academy of Management Journal, Vol. 50, No. 1, pp. 25-32.

Elliot, J. (1991), Action Research for Educational Change, McGraw-Hill Education, UK.

Geertz, C. (1975), 'On the Nature of Anthropological Understanding: Not extraordinary empathy but readily observable symbolic forms enable the anthropologist to grasp the unarticulated concepts that inform the lives and cultures of other peoples', American Scientist, Vol. 63, No. 1, pp. 47-53.

Golsteyn, B. and Schildberg-Hörisch, H. (2017), 'Challenges in research on preferences and personality traits: Measurement, stability, and inference', Journal of Economic Psychology, Vol. 60, pp. $1-6$.

Gunder, M. (2010), 'Making planning theory matter: A Lacanian encounter with Phronesis', International Planning Studies, Vol. 15, No. 1, pp. 37-51.

Harre, R. (2012), 'Positioning Theory: Moral Dimensions of Social-Cultural Psychology'. In J. Valsiner (Ed.) Oxford Handbook of Culture and Psychology, Oxford: Oxford University Press, Oxford.

Helfat, C. E. and Peteraf, M. A. (2003), 'The dynamic resource-based view: Capability lifecycles', Strategic Management Journal, Vol. 24, No. 10, pp. 997-1010. 
Hill, C. E. and Lent, R. W. (2006), 'A narrative and meta-analytic review of helping skills training: Time to revive a dormant area of inquiry', Psychotherapy: Theory, Research, Practice, Training, Vol. 43, No. 2, p. 154.

Husserl, E. (1965), Phenomenology and the Crisis of Philosophy, (Quentin Lauer Trans.) Harper and Row, NY.

James, M. (2010), 'A Provisional Conceptual Framework for Intentional Positioning in Public Relations', Journal of Public Relations Research, Vol. 23, No. 1, pp. 93 - 118.

James, M. (2014), Positioning Theory and Strategic Communications: A New Approach to Public Relations Research and Practice, London: Routledge, London.

Jansson, N. (2014), 'Discourse phronesis in organisational change: a narrative analysis', Journal of Organisational Change Management, Vol. 27, No. 5, pp. 769 - 779.

Kelly, D. and Amburgey, T. L. (1991), 'Organizational inertia and momentum: A dynamic model of strategic change', Academy of Management Journal, Vol. 34, No. 3, pp. 591-612.

Kjaerbeck, S. (2017), 'Positioning and change in a hospital ward', Journal of Organisational Change Management, Vol. 30, No. 1, pp. 43 - 53.

Knowles, E. S. and Linn, J. A. (2004b), 'The importance of resistance to persuasion'. In E.S. Knowles and J. A. Linn (Eds.) Resistance and Persuasion, 3 - 9, New Jersey: Lawrence Erlbaum Associates, New Jersey.

Kotter, J. P. and Schlesinger, L. (1979), 'Choosing strategies for change', Harvard Business Review, Vol. 57, No. 2, pp. $106-114$.

Latour, B. (2005), Reassembling the Social: An Introduction to Actor-Network Theory, Oxford University Press, Oxford.

Mendy, J. (2019), 'Supporting Creating Shared Value: Including Local and Global Clusters of Staff Resistance to Strategic SME Restructuring', Strategic Change Journal Special Issue on 'Supporting Creating Shared Value', Vol. 28, No. 2, pp. 157 - 161.

Mendy, J. (2018), 'Rethinking the Contribution of Organizational Change to the Teaching and Learning of Organizational Behaviour and Human Resource Management: The Quest for Balance'. In Teaching Human Resources and Organizational Behavior at the College Level, IGI Global, PA. (pp. 103-132).

Miles, M. B. and Huberman, A. M. (1994), Qualitative data analysis: An expanded Sourcebook, Sage, CA.

Myers, M. D. (2013), Qualitative Research in Business and Management, Sage, US.

Orlikowski, W. (2007), 'Sociomaterial practices: exploring technology at work', Organization Studies, Vol. 8, No. 9, pp. 1435 - 1448. 
Piderit, S. K. (2000), 'Rethinking resistance and recognising ambivalence: a multidimensional view of attitudes toward an organizational change', Academy of Management Review, Vol. 25, No. 4, pp. $783-794$.

Prigogine, I. and Stengers, I. (2018), Order out of chaos: Man's new dialogue with nature. Verso Books, New York.

Pryor, M. G., Anderson, D. A., Toombs, L. A. and Humphreys, J. (2007), 'Strategic Implementation as a Core Competency', Journal of Management Research, April.

Reckwitz, A. (2002), 'Toward a theory of social practices: A development in culturalist theorizing', European Journal of Social Theory, Vol. 5, No. 2, pp. 243-263.

Rouleau, L. and Balogun, J. (2011), 'Middle Managers, Strategic Sense-making and Discursive Competence', Journal of Management Studies, Vol. 48, No. 5, pp. 953 - 983.

Sanders, K., Shipton, H. and Gomes, J. F. S. (2014), 'Is the HRM Process Important? Past, Current and Future Challenges', Human Resource Management, Vol. 53, No. 4, pp. 489 - 503. Schutz, A. (1967), The Phenomenology of the Social World, Northwestern University Press, US.

Senior, B. (2002), Organisational Change. Prentice Hall, London.

Smith, W. K. and Lewis, M. W. (2011), 'Toward a theory of paradox: A dynamic equilibrium model of organizing', Academy of Management Review, Vol. 36, No. 2, pp. 381-403.

Smith, J. A., Flowers, P. and Larkin, M. (2009), Interpretative Phenomenological Analysis:

Theory, Method and Research. Sage, US.

Todnem By, R. (2005), 'Organisational change management: A critical review', Journal of Change Management, Vol. 5, No. 4, pp. 369-380.

Vaara, E. and Tienari, J. (2011), 'On the narrative construction of multinational corporations: an antenarrative analysis of legitimation and resistance in a cross-border merger', Organization Science, Vol. 22, No. 2, pp. 370 - 390.

Welch, C., Piekkari, R., Plakoyiannaki, E. and Paavilainen-Mäntymäki, E. (2011), Theorising from case studies: Towards a pluralist future for international business research. Journal of International Business Studies, Vol. 42, No. 5, pp. 740-762.

Wischnevsky, J. D. (2004), 'Change as the Winds Change: The Impact of Organisational Transformation on Firm Survival in a Shifting Environment', Organisational Analysis, Vol. 12, No. 4 , pp. $361-377$.

Yin, R. K. (2003), Case Study Research - Design and Methods (3rd Ed.), Sage, UK. Yin, R. K. (1994), Case Study Research - Design and Methods (2nd Ed.), Sage, California. 


\begin{tabular}{|c|c|c|c|}
\hline Companies \& change aspects & Respondent types in 2004/05 & Respondent types in 2011 & Respondents' socio-demographics \\
\hline $\begin{array}{l}\text { Bakkavor-Laurens } \\
\text { Integration of working practices with } \\
\text { parent company for more effective } \\
\text { service delivery }\end{array}$ & $\begin{array}{l}5 \text { operatives ( } 3 \text { males \& } 2 \text { females), } 2 \\
\text { drivers (males), } 2 \text { outer-packers (males) } \\
\& 1 \text { cleaner (female) }+4 \text { supervisors }(3 \\
\text { males \& } 1 \text { female) \& } 3 \text { senior managers } \\
\text { (males) }\end{array}$ & $\begin{array}{l}1 \text { operative } \& 1 \text { outer-packer }+1 \\
\text { systems manager (male) \& } 1 \text { financial } \\
\text { controller (male) }\end{array}$ & $\begin{array}{l}3 \text { operatives }-18-40 \text { years; } 1 \text { operative } \\
\text { - between } 40 \text { - } 59 \text { years; } 2 \text { operatives - } \\
\text { over } 60 \text { years; } 1 \text { driver - between } 25- \\
29 \text { years; } 1 \text { driver -between } 30-40 \\
\text { years; } 2 \text { outer-packers - between } 17- \\
35 \text { years; } 1 \text { outer-packer - over } 40 \text { years; } \\
1 \text { cleaner - } 27 \text { years; } 2 \text { supervisors - } \\
\text { between } 20-39 \text { years; } 2 \text { supervisor - } \\
\text { between } 40-45 \text { years; } 3 \text { senior } \\
\text { managers - between } 40-65 \text { years }\end{array}$ \\
\hline $\begin{array}{l}\text { Longhurst Housing } \\
\text { Modernise housing provision to meet } \\
\text { regulatory standards and greater } \\
\text { profitability }\end{array}$ & $\begin{array}{l}2 \text { receptionists (females), } 4 \text { fitters } \\
\text { (males), } 2 \text { painters and decorators } \\
\text { (males) \& } 2 \text { builders (males); } 1 \mathrm{HR} \\
\text { Director (male), } 3 \text { Maintenance } \\
\text { Managers ( } 2 \text { females \& } 1 \text { male), } 1 \\
\text { Information Manager (female), } 1 \\
\text { Construction Head (male), } 1 \text { Quality } \\
\text { Manager (female) }\end{array}$ & $\begin{array}{l}1 \text { receptionist \& } 1 \text { fitter }+1 \text { HR Director } \\
\& 1 \text { Maintenance Manager }\end{array}$ & $\begin{array}{l}3 \text { Receptionists - between } 18-25 \text { years, } \\
1 \text { fitter - } 20 \text { years; } 4 \text { fitters - between } 25 \\
-30 \text { years; } 2 \text { painters/decorators - } \\
\text { between } 19-27 \text { years; } 2 \text { builders - } \\
\text { between } 21 \text { - } 26 \text { years; Director - over } \\
50 \text { years; } 2 \text { maintenance managers - } \\
\text { between } 50 \text { - } 60 \text { years; } 2 \text { maintenance } \\
\text { managers - between } 30 \text { - } 35 \text {, } \\
\text { information manager - over } 30 \text { years, } \\
\text { construction head - over } 25 \text { years \& } \\
\text { quality manager - over } 40 \text { years. }\end{array}$ \\
\hline $\begin{array}{l}\text { Eden Housing } \\
\text { Readiness for UK expansion \& growth } \\
\text { led to staff reskilling }\end{array}$ & $\begin{array}{l}1 \text { receptionist (female), } 4 \text { care workers } \\
\text { (females), } 1 \text { cleaner (female), } 2 \text { accounts } \\
\text { clerks ( } 1 \text { male \& } 1 \text { female) \& } 2 \text { office } \\
\text { staff (females); } 1 \text { HR Manager (female), } \\
2 \text { Property Managers (females), } 4 \\
\text { Supervisors ( } 1 \text { male \& } 3 \text { females) }\end{array}$ & $\begin{array}{l}1 \text { receptionist \& } 1 \text { care workers \& } 1 \text { HR } \\
\text { Manager \& } 1 \text { Property Manager }\end{array}$ & $\begin{array}{l}2 \text { receptionists - between } 20-34 \text { years, } \\
5 \text { care workers - between } 18-37 \text { years, } \\
1 \text { cleaner - over } 25 \text { years, } 2 \text { accountant } \\
\text { clerks - between } 23-35 \text { years } \& 2 \\
\text { office staff - between } 18-30 \text { years; } 1 \\
\text { HR Manager - over } 30 \text { years, } 3 \text { Property } \\
\text { Managers - between } 33-45 \text { years, } 4 \\
\text { Supervisors - between } 25-40 \text { years }\end{array}$ \\
\hline $\begin{array}{l}\text { Education market pressures prompted } \\
\text { need for behavioural \& service delivery } \\
\text { changes }\end{array}$ & $\begin{array}{l}4 \text { Training officers (females), } 3 \\
\text { Learning Advisors (females), } 2 \text { Personal } \\
\text { Assistants (females), } 1 \text { Business } \\
\text { Advisor (male), } 1 \text { Managing Director } \\
\text { (female), } 2 \text { Operations Managers ( } 1 \\
\text { male \& } 1 \text { female), } 4 \text { Supervisors ( } 1 \text { male } \\
\& 3 \text { females) }\end{array}$ & $\begin{array}{l}1 \text { Training officer, } 1 \text { Personal Assistant, } \\
1 \text { Managing Director \& } 1 \text { Operations } \\
\text { Manager }\end{array}$ & $\begin{array}{l}5 \text { Training officers - between } 25-42 \\
\text { years, } 3 \text { Learning Advisors - between } \\
31-50 \text { years, } 3 \text { Personal Assistants - } \\
\text { between } 23-30 \text { years, } 1 \text { Business } \\
\text { Advisor - over } 40 \text { years, } 1 \text { Managing } \\
\text { Director - over } 50 \text { years, } 3 \text { Operations } \\
\text { Managers - between } 35-44 \text { years, } 4 \\
\text { Supervisors - between } 24-56 \text { years }\end{array}$ \\
\hline
\end{tabular}


Table 1. Companies, respondent types and varied socio-demographics

\begin{tabular}{|l|l|l|l|}
\hline SME cases \& types & Issues in each case & Interview guideline per case in 2004/05 & Interview guideline per case in 2011 \\
\hline $\begin{array}{l}\text { Bakkavor-Laurens } \\
\text { (manufacturing) }\end{array}$ & $\begin{array}{l}\text { Dealing with merger and acquisition, expanding } \\
\text { into Europe and Far East, streamlining work } \\
\text { processes }\end{array}$ & $\begin{array}{l}\text { What changes have happened and what are } \\
\text { your experiences of these? }\end{array}$ \\
then. \\
\hline $\begin{array}{l}\text { Longhurst Housing } \\
\text { (construction) }\end{array}$ & $\begin{array}{l}\text { Complying with housing legislation, dealing } \\
\text { with redundancies from acquired businesses, } \\
\text { changing working practices }\end{array}$ & $\begin{array}{l}\text { Have there been changes to your company's } \\
\text { working practices and your role? }\end{array}$ & $\begin{array}{l}\text { What employees and managers have done in } \\
\text { the way they carry out their roles as a result of } \\
\text { company changes. }\end{array}$ \\
\hline $\begin{array}{l}\text { Eden Housing (care) } \\
\text { Lagat }\end{array}$ & $\begin{array}{l}\text { Expanding into other UK regions, becoming a } \\
\text { more profitable business, developing new } \\
\text { policies in line with acquiring company }\end{array}$ & $\begin{array}{l}\text { Have you experienced any difficulties in } \\
\text { relation to changes to your job? }\end{array}$ & $\begin{array}{l}\text { Practical actions taken to deal with the } \\
\text { difficulties raised by job changes. }\end{array}$ \\
\hline counselling) & $\begin{array}{l}\text { Pressures from other education providers, } \\
\text { increased staff workload, changes to service } \\
\text { outreach and greater efficiencies }\end{array}$ & $\begin{array}{l}\text { Have you experienced any challenges in } \\
\text { carrying out your job and in the way training } \\
\text { and development are organised? }\end{array}$ & $\begin{array}{l}\text { Actions taken to address challenges to } \\
\text { training and development are organised. }\end{array}$ \\
\hline
\end{tabular}

Table 2. Methodological aspects

\begin{tabular}{|l|l|l|l|l|l|}
\hline SME cases & $\mathbf{2 0 0 4 / 0 5}$ Situation & 2011 Situation & Changes & $\begin{array}{l}\text { Staff \& } \\
\text { Management } \\
\text { experiences }\end{array}$ \\
\hline Bakkavor-Laurens & $\begin{array}{l}\text { Increasing demand } \\
\text { for cake products }\end{array}$ & $\begin{array}{l}\text { Integrate with new } \\
\text { parent company in } \\
\text { Iceland, being more } \\
\text { financially/profit- } \\
\text { driven }\end{array}$ & $\begin{array}{l}\text { New management } \\
\text { system, } \\
\text { diversification of } \\
\text { Recruitment bases to } \\
\text { Include Africa and } \\
\text { Asia, changes in } \\
\text { Company policies } \\
\text { and procedures to } \\
\text { cater for new recruits } \\
\text { and culture }\end{array}$ & $\begin{array}{l}\text { Increased work shift } \\
\text { patterns, increased } \\
\text { Working hours }\end{array}$ & $\begin{array}{l}\text { Tensions between } \\
\text { Bakkkavor, UK and } \\
\text { parent company in } \\
\text { adoption and use of } \\
\text { parent company's } \\
\text { policies and practices, } \\
\text { cultural conflicts } \\
\text { Between UK, African } \\
\text { \& Asian staff }\end{array}$ \\
& & $\begin{array}{l}\text { Monitor departments } \\
\text { and conflicts between } \\
\text { staff \& between staff } \\
\text { and management }\end{array}$ \\
\end{tabular}




\begin{tabular}{|c|c|c|c|c|c|c|}
\hline Longhurst Housing & $\begin{array}{l}\text { Increased number } \\
\text { Of customers }\end{array}$ & $\begin{array}{l}\text { Modernise service, } \\
\text { being more customer } \\
\text { focused }\end{array}$ & $\begin{array}{l}\text { More specialised } \\
\text { Staff required with } \\
\text { financial } \\
\text { acumen, changes in } \\
\text { performance criteria } \\
\& \text { target setting }\end{array}$ & $\begin{array}{l}\text { Staff expected to } \\
\text { make changes work, } \\
\text { Additional } \\
\text { supervision and } \\
\text { Monitoring of task } \\
\text { execution and target } \\
\text { achievements }\end{array}$ & $\begin{array}{l}\text { Staff found new } \\
\text { performance regime } \\
\text { a challenge to meet, } \\
\text { new skills required } \\
\text { meant additional time } \\
\text { in upgrading } \\
\text { individual } \\
\text { competences }\end{array}$ & $\begin{array}{l}\text { Key Performance } \\
\text { Indicators introduced } \\
\text { to measure staff } \\
\text { performance, greater } \\
\text { frequency in } \\
\text { supervising and } \\
\text { monitoring target } \\
\text { achievement }\end{array}$ \\
\hline Eden Housing & $\begin{array}{l}\text { Increasing variety of } \\
\text { Disability and health } \\
\text { issues }\end{array}$ & $\begin{array}{l}\text { Expand to other areas } \\
\text { of the UK, merge } \\
\text { with other profitable } \\
\text { firms as dictated by } \\
\text { new firm }\end{array}$ & $\begin{array}{l}\text { Staff expected to } \\
\text { cover wider areas to } \\
\text { reach out to disabled } \\
\text { patients, office staff } \\
\text { took on additional } \\
\text { care roles }\end{array}$ & $\begin{array}{l}\text { Additional } \\
\text { responsibilities for } \\
\text { existing and } \\
\text { incoming staff }\end{array}$ & $\begin{array}{l}\text { Management and } \\
\text { staff interactions } \\
\text { became strained, } \\
\text { Profit orientation } \\
\text { sapped the previous } \\
\text { Friendly working } \\
\text { environment, staff } \\
\text { were pushed to } \\
\text { deliver financial } \\
\text { returns without } \\
\text { adequate training }\end{array}$ & $\begin{array}{l}\text { New firm's } \\
\text { management imposed } \\
\text { new working } \\
\text { practices geared } \\
\text { towards maximisation } \\
\text { of profit, } \\
\text { increased scrutiny of } \\
\text { old staff via meetings } \\
\text { and one-to-one } \\
\text { sessions }\end{array}$ \\
\hline Lagat & $\begin{array}{l}\text { Provide increasing } \\
\text { range of education } \\
\text { and counselling } \\
\text { services to students }\end{array}$ & $\begin{array}{l}\text { Market pressures, } \\
\text { Reduced government } \\
\text { Financial support }\end{array}$ & $\begin{array}{l}\text { New managers } \\
\text { appointed, staff } \\
\text { redundancies, merge } \\
\text { with Connexions, } \\
\text { greater efficiencies, } \\
\text { new set of working } \\
\text { practices and } \\
\text { reporting procedures }\end{array}$ & $\begin{array}{l}\text { Increased workload } \\
\text { and greater } \\
\text { geographical } \\
\text { coverage by Learning } \\
\text { Advisors }\end{array}$ & $\begin{array}{l}\text { Staff found the } \\
\text { Wider geographic } \\
\text { areas they have to } \\
\text { scout for student } \\
\text { clients demanding, no } \\
\text { additional incentives } \\
\text { were given for wider } \\
\text { staff and management } \\
\text { roles }\end{array}$ & $\begin{array}{l}\text { Middle line Managers } \\
\text { were appointed } \\
\text { to monitor activities } \\
\text { of Learning Advisors, } \\
\text { greater reporting } \\
\text { to senior management } \\
\text { of acquiring company }\end{array}$ \\
\hline
\end{tabular}

Table 3. Findings in 2004/05 and 2011

\begin{tabular}{|l|l|l|l|}
\hline SME cases in Stage 1 Change & Changes & Experiences & Difficulties \\
\hline Bakkavor-Laurens & $\begin{array}{l}\text { Managers introduced new } \\
\text { structures and disciplinary } \\
\text { procedures to monitor staff } \\
\text { performance and conduct }\end{array}$ & $\begin{array}{l}\text { Staff felt pressurised with } \\
\text { threats of disciplinary action, } \\
\text { Managers increased monitoring }\end{array}$ & $\begin{array}{l}\text { Clashes between management } \\
\text { and staff \& among staff of } \\
\text { different nationalities posed } \\
\text { problems }\end{array}$ \\
\hline
\end{tabular}




\begin{tabular}{|l|l|l|l|}
\hline Longhurst Housing & $\begin{array}{l}\text { Managers introduced an } \\
\text { expansion plan and working } \\
\text { practices to measure staff's } \\
\text { attainment of targets }\end{array}$ & $\begin{array}{l}\text { Staff were torn between } \\
\text { Customer satisfaction and } \\
\text { company's financial viability, } \\
\text { managers increased practices } \\
\text { for financial sustainability }\end{array}$ & $\begin{array}{l}\text { The new performance } \\
\text { indicators and targets increase } \\
\text { absence levels and hampered } \\
\text { achievement rates }\end{array}$ \\
\hline Eden Housing & $\begin{array}{l}\text { Introduction of new } \\
\text { performance indicators to } \\
\text { boost profit margins } \\
\text { Introduced surveys to }\end{array}$ & $\begin{array}{l}\text { Managers introduced new } \\
\text { disciplinary procedures and } \\
\text { expected staff to comply. Staff } \\
\text { felt they needed training in care } \\
\text { quality issues }\end{array}$ & $\begin{array}{l}\text { Lack of friendly working } \\
\text { Environment created identity } \\
\text { silos and created divisions } \\
\text { between Eden staff and } \\
\text { management and the new } \\
\text { owning company }\end{array}$ \\
\hline Lagat & $\begin{array}{l}\text { Managers also doubled up as } \\
\text { anternal Verifiers for } \\
\text { ensure all staff complied with } \\
\text { new working procedures } \\
\text { assurance }\end{array}$ & $\begin{array}{l}\text { Staff felt being asked to do a lot } \\
\text { with no salary increment, } \\
\text { managers introduced another } \\
\text { supervision layer on staff }\end{array}$ & $\begin{array}{l}\text { Wider geographic coverage } \\
\text { areas stretched staff resources, } \\
\text { with no guarantee of increased } \\
\text { student uptake }\end{array}$ \\
\hline
\end{tabular}

Table 4. SMEs in Stage 1 Change

\begin{tabular}{|l|l|l|l|}
\hline SME cases in Stage 2 Change & Changes & Experiences & Difficulties \\
\hline $\begin{array}{l}\text { Bakkavor- } \\
\text { Laurens }\end{array}$ & $\begin{array}{l}\text { The new owners tried to start a } \\
\text { new culture by introducing } \\
\text { the parent company's processes } \\
\text { Managers' interpretation of the } \\
\text { new policies was not well } \\
\text { received by existing staff. } \\
\text { New staff outside the UK tried } \\
\text { to adapt the policies in line with } \\
\text { their culture }\end{array}$ & $\begin{array}{l}\text { Commanicating the new culture } \\
\text { wallenging for managers, } \\
\text { managers' plans } \\
\text { policies and procedures and set } \\
\text { up communication boards to } \\
\text { help maintain } \\
\text { adherence/compliance, } \\
\text { employees started their own } \\
\text { communication } \\
\text { networks }\end{array}$ & $\begin{array}{l}\text { Managers formalised HR } \\
\text { sanagers started customer } \\
\text { satisfaction teams to improve } \\
\text { quality and service provision, } \\
\text { HR started recruiting staff with } \\
\text { necessary skills }\end{array}$ \\
\hline Longhurst Housing & $\begin{array}{l}\text { Managers introduced quality } \\
\text { standards to improve services }\end{array}$ & $\begin{array}{l}\text { Staff felt frustrated with the } \\
\text { new targets and performance } \\
\text { measures, managers were under } \\
\text { external pressure to deliver } \\
\text { affordable and quality housing } \\
\text { services }\end{array}$ & $\begin{array}{l}\text { Communication breakdown } \\
\text { Between management and staff }\end{array}$ \\
\hline $\begin{array}{l}\text { Eden } \\
\text { Housing }\end{array}$ & $\begin{array}{l}\text { Staff felt ill equipped to } \\
\text { maintain productivity, } \\
\text { managers came under scrutiny } \\
\text { to deliver }\end{array}$ & $\begin{array}{l}\text { Working relations between the } \\
\text { various parties deteriorated } \\
\text { performance enhancement } \\
\text { mechanisms }\end{array}$ & $\begin{array}{l}\text { Communicating the } \\
\text { new working practices } \\
\text { became more } \\
\text { controlled by the new }\end{array}$ \\
\hline
\end{tabular}




\begin{tabular}{|l|l|l|l|}
\hline & & & owning company \\
\hline Lagat & $\begin{array}{l}\text { Managers made the Internal } \\
\text { Verifier role redundant and } \\
\text { integrated this function into } \\
\text { their positions }\end{array}$ & $\begin{array}{l}\text { Remaining staff felt vulnerable, } \\
\text { Managers shared experiences } \\
\text { with other managers }\end{array}$ & $\begin{array}{l}\text { Pockets of communication } \\
\text { silos emerged, role groups } \\
\text { became segregated }\end{array}$ \\
\hline
\end{tabular}

Table 5. SMEs in Stage 2 Change

\begin{tabular}{|c|c|c|c|c|}
\hline SME cases in Stage 3 Change & Changes & Experiences & Difficulties & Actions \\
\hline $\begin{array}{l}\text { Bakkavor- } \\
\text { Laurens }\end{array}$ & $\begin{array}{l}\text { Staff created new network and } \\
\text { collaborations across } \\
\text { departments }\end{array}$ & $\begin{array}{l}\text { Managers felt threatened, staff } \\
\text { felt they could contribute } \\
\text { differently }\end{array}$ & $\begin{array}{l}\text { Managers started to resist } \\
\text { staff's actions }\end{array}$ & $\begin{array}{l}\text { Staff redefined and formalised } \\
\text { tasks; managers reinforced } \\
\text { disciplinary measures; staff } \\
\text { encouraged colleagues to } \\
\text { communicate new tasks to } \\
\text { colleagues }\end{array}$ \\
\hline Longhurst Housing & $\begin{array}{l}\text { Staff started 'dipping' into } \\
\text { others' roles }\end{array}$ & $\begin{array}{l}\text { Staff felt elated, managers } \\
\text { sensed a shift }\end{array}$ & $\begin{array}{l}\text { The silo collaborations } \\
\text { Further separated the role } \\
\text { groups and threatened housing } \\
\text { operations }\end{array}$ & $\begin{array}{l}\text { Staff altered job definitions, } \\
\text { Managers reinforced HR's } \\
\text { role as a policing function }\end{array}$ \\
\hline Eden Housing & $\begin{array}{l}\text { Staff volunteered to perform } \\
\text { duties beyond their remits }\end{array}$ & $\begin{array}{l}\text { Staff thought they were helping } \\
\text { out patients, managers took this } \\
\text { to their advantage }\end{array}$ & $\begin{array}{l}\text { Managers realised their } \\
\text { positions were being taken over } \\
\text { by staff, staff became less } \\
\text { receptive of new company } \\
\text { owners' instructions }\end{array}$ & $\begin{array}{l}\text { Staff started 'doing' their } \\
\text { jobs again by identifying core } \\
\text { elements, managers ensured } \\
\text { frequency of meetings to stem } \\
\text { negative impacts }\end{array}$ \\
\hline
\end{tabular}




\begin{tabular}{|c|c|c|c|c|}
\hline Lagat & $\begin{array}{l}\text { Managers reinvented additional } \\
\text { roles to legitimise their } \\
\text { positions, staff resisted by } \\
\text { creating their own functions }\end{array}$ & $\begin{array}{l}\text { Managers felt challenged, staff } \\
\text { saw the new situation as an } \\
\text { opportunity }\end{array}$ & $\begin{array}{l}\text { Managers created their culture } \\
\text { webs to curtail staff's growing } \\
\text { influence, staff stepped out of } \\
\text { managers' traditional command } \\
\text { and control structures }\end{array}$ & $\begin{array}{l}\text { Managers started doubling } \\
\text { up by taking additional } \\
\text { responsibilities, staff cemented } \\
\text { their control on new } \\
\text { collaborations }\end{array}$ \\
\hline
\end{tabular}

